\title{
Microbial cellulases immobilized in biopolymer/silica matrices used as enzyme release systems
}

\author{
Monica Dragomirescu' ${ }^{1}$, Teodor Vintila1', Titus Vlase², Ciprian-Valentin Mihali ${ }^{3,4}$ and \\ Gabriela Preda2区
}

1Department of Biotechnologies, Bioengineering Faculty of Animal Resources, Banat's University of Agricultural Science and Veterinary Medicine "King Michael I of Romania" from Timişoara, Timişoara, Romania; 2Department of Biology-Chemistry, Faculty of Chemistry, Biology, Geography, West University of Timişoara, Timişoara, Romania; ${ }^{3}$ Department of Experimental and Applied Biology, Institute of Life Sciences, Vasile Goldis Western University of Arad, Arad, Romania; ${ }^{4}$ Molecular Biology Laboratory, Research and Development Station for Bovine, Arad, Romania

\begin{abstract}
Trichoderma viride CMGB 1 cellulases were immobilized by entrapment in silica gels (by the sol-gel method), alginate biopolymers and hybrid alginate/silica materials. Tetramethoxysilane (TMOS), tetraethoxysilane (TEOS) and tetrakis (2-hydroxyethyl) orthosilicate (THEOS) were used as organoalkoxysilane precursors, and ethanol or ethylene glycol (EG) as cosolvents in a two-step sol-gel synthesis. Combined alginate/silica matrices were obtained by mixing the silica sol with sodium alginate or by coating alginate beads with a silica shell. A partial confinement of ethylene glycol in the matrix and its consequences on biocatalytic activity were investigated using scanning electron microscopy-Energy Dispersive X-Ray Analysis (SEM-EDAX), Fourier-transform infrared spectroscopy (FT-IR). The efficiency of the enzyme-matrix biomaterials was tested in controlled enzyme release experiments. The sol-gel method developed using EG as a co-solvent allowed cellulase immobilization yields that were 1.5-4.5 times higher when compared to classical sol-gel methods that use EtOH. Characterization of the gels by microscopic and spectrophotometric analyses showed that there are similarities between the structure of the gels based on THEOS and those developed by us from TEOS, TMOS and EG as co-solvents. The gels developed here showed good cellulase release properties at acidic $\mathrm{pH}$, comparable to those based on THEOS and alginate. Microbial cellulases immobilized in the matrices obtained here and characterized in this work can operate as efficient systems for releasing enzymes, at acidic $\mathrm{pH}$ conditions, as feed additives.
\end{abstract}

Keywords: cellulases; entrapment; sol-gel; THEOS; ethylene glycol; alginate/silica matrices

Received: 08 May, 2021; revised: 10 July, 2021; accepted: 11 July, 2021; available on-line: 30 September, 2021

⿶e-mail: gabriela.preda@e-uvt.ro

Abbreviations: EG, ethylene glycol; FT-IR, Fourier-transform infrared spectroscopy; SEM-EDAX, scanning electron microscopyEnergy Dispersive X-Ray Analysis; TEOS, tetraethoxysilane; THEOS, tetrakis (2-hydroxyethyl) orthosilicate; TMOS, Tetramethoxysilane

\section{INTRODUCTION}

Cellulases are a group of enzymes (exo- and endoglucanases, cellobiases) that can hydrolyze cellulose from biomass to oligosaccharides and glucose. Biomass certainly will be a valuable resource in a sustainable bioeconomy (Bhat, 2000; Das et al., 2011; Singhania et al., 2010). Cellulases or related enzymes are also widely used in brewery and wine, textile and detergent, pulp and paper industries (Dinçer \& Telefoncu, 2007). There is an increasing need for cellulases on the market for bioconversion of lignocellulosic biomass to bioethanol or other bio-based products, and also for food and animal feed products (Bhat, 2000; Singhania et al., 2010, Wongwilaiwalin et al., 2010; Takimoto et al., 2008).

For an efficient hydrolysis of cellulose-based woody and non-woody biomass in industrial and agricultural applications, active and stable cellulases are needed. Enzymes' stabilization by immobilization increases their usability, as well as the number and diversity of specific applications (Dinçer \& Telefoncu, 2007; Das et al., 2011; Yang et al., 2021, Haodao et al., 2020, Zheng et al., 2019).

Only a few articles deal with the entrapment/encapsulation of cellulases in polymeric structures, probably because the low solubility of substrates and low diffusion of cellulose, a macromolecular substrate, in the matrix may diminish the enzyme's activity. Due to the growing interest in efficiently stabilized cellulases in biomass transformation processes, most of such papers were published in recent years (Haodao et al., 2020, Zheng et al., 2019, Ajay \& Sangeeta, 2020; Wei et al., 2020, Yonca et al., 2020).

Entrapment in the sol-gel matrices could be a promising alternative to improve stability and reusability of cellulases with less alteration in their catalytic efficiency (Paljevac et al., 2007; Jin \& Breman, 2002; Avnir et al., 1994; Gill \& Ballesteros, 2000; Livage et al., 2001; Kim et al., 2006). The sol-gel process is used to obtain inorganic or hybrid biocompatible nano or mesostructured materials under mild conditions, usually using tetramethoxysilane (TMOS) or tetraethoxysilane (TEOS) as gel precursors (Kim et al., 2006; Shchipunov et al., 2004; Reetz et al., 1996; Kim et al., 2001; Park \& Clark, 2002; Reetz et al., 2000; Zarcula et al., 2009; Sangeetha et al., 2008). TMOS, a commonly used precursor (Brinker \& Scherer, 1990), undergoes a rapid and exothermic hydrolysis and, for this reason, may affect the enzyme stability. TEOS is a less reactive, less toxic and cheaper precursor. The sol-gel synthesis used by us followed a two-step procedure, the sol synthesis from TMOS or TEOS in acid catalysis, and gelling with $\mathrm{NaF}$ as the catalyst. To diminish enzyme inactivation during the sol and gel synthesis, gel aging and drying, more friendly precursors and reaction environment (organic solvent or hydrolysis or/and condensation catalysts) are advisable. THEOS is such a water-miscible and biocompatible precursor, with high potential for enzyme entrapment (Kim et al., 2001; Nochos et al., 2008; Paljevac et al., 2007; Shchipunov et al., 2004; Shchipunov et al., 2005; Bakunina et al., 2006). 
We report here the entrapment of Trichoderma viride cellulase in silica matrices by using THEOS as the gel precursor. We also report on the use of aged sols based on ethylene glycol, an agent compatible with both, the sol-gel process and the enzyme molecules (Husing et al., 2006). Our research attempted to mimic the microenvironment produced by THEOS, using TEOS or TMOS precursors and ethylene glycol as the co-solvent. We also immobilized cellulases in hybrid organic-inorganic matrices, i.e. alginate-silica gels based on THEOS as the gel precursor. The activity and operational parameters of the immobilized cellulases, and the potential of these bioorganic materials as enzyme release systems with application in animal feeding were investigated. The influence of the sol-gel process on the catalytic efficiency was investigated based on the thermal behaviour of the gels, scanning electron microscopy (SEM) images and Fourier-transform infrared (FT-IR) spectra.

\section{MATERIALS AND METHODS}

\section{Materials}

Carboxymethyl cellulose sodium salt (CMC, low viscosity), cellobiose, (+)-glucose, hexane, Folin-Ciocalteu's phenol reagent, bovine serum albumin (BSA) and tetraethoxysilane (TEOS) were purchased from Merck. 3,5-dinitrosalicylic acid (DNS), alginic acid sodium salt, citric acid and tetramethoxysilane (TMOS) were obtained from Fluka. Tetrakis (2-hydroxiethyl) orthosilicate (THEOS) and potassium sodium tartrate tetrahydrate were from Sigma - Aldrich. Ethylene glycol (EG) was from Scharlau, ethanol and $\mathrm{CaCl}_{2}$ sicc. from Chimopar. The Trichoderma viride $\mathrm{CMGB} 1$ strain was preserved in the collection of industrial microorganisms of the Industrial Microbiology Laboratory of USAMVB Timisoara, Romania. All other chemicals were obtained from local suppliers or were commercially available reagent grade products, and were used without further purification.

\section{Enzyme biosynthesis}

Microbial cells of Trichoderma viride CMGB 1 were cultured in solid state fermentation and the fermentation medium was processed according to the method described in (Mitchell, 1992; Lange, 2007; Dragomirescu et al., 2012).

\section{Immobilization procedure}

\section{Procedure 1. Entrapment in silica gels}

a. The immobilized CMCase samples, obtained by using TEOS and TMOS as silica precursors, were prepared based on the Reetz procedure (Reetz et al., 2003). TEOS or TMOS (3 mmol), alcohol $(0.5 \mathrm{~mL}$ ethanol or ethylene glycol $)$, water $(0.2 \mathrm{~mL}$ in the case of ethanol) and $0.1 \mathrm{~N} \mathrm{HCl}(10 \mu \mathrm{L})$ were mixed till a clear solution of sol was obtained. The Trichoderma viride CMCase powder was suspended in $0.1 \mathrm{M}$ citric acid - $0.2 \mathrm{M} \mathrm{Na}_{2} \mathrm{H}$ $\mathrm{PO}_{4}$ buffer solution, $\mathrm{pH} 4.6$, stirred at room temperature, centrifuged $5 \mathrm{~min}$ at $25^{\circ} \mathrm{C}$ and $6000 \mathrm{rpm}$ (Micro centrifuge, Roth, Germany), and the supernatant was used for immobilization. $0.7 \mathrm{~mL}$ of supernatant (40 enzyme units if not mentioned otherwise) and $50 \mu \mathrm{L}$ of $1 \mathrm{M}$ $\mathrm{NaF}$ were added, and the sample was mixed for 30-60 seconds till gelling. The gel was kept for $24 \mathrm{~h}$ at $4^{\circ} \mathrm{C}$ for aging, washed with hexane $(5 \mathrm{~mL})$ and water $(5 \mathrm{~mL})$ under stirring, filtered and dried under vacuum (G1, G2,
G4, G5). In an alternative procedure, the sol was kept for aging at $4^{\circ} \mathrm{C}$ for 20 days, and used for enzyme entrapment as described (G3, G6).

b. The immobilization method was based on the Shchipunov procedure (Shchipunov et al., 2004). 0.78 $\mathrm{mL}$ of the centrifuged enzyme solution (usually 40 enzyme units) and THEOS (3 mmoles) were stirred at room temperature until gelling. The gel was treated as described in Procedure 1a (G7).

\section{Procedure 2. Entrapment in alginate hydrogels}

The method described by Konsoula \& LiakopoulouKyriakides (Konsoula \& Liakopoulou-Kyriakides, 2006) was adapted as follows: $2 \%$ sodium alginate solution $(1.18 \mathrm{~mL})$ was mixed with $0.7 \mathrm{~mL}$ of the centrifuged enzyme solution (40 enzyme units), and dropped with a syringe needle in a $0.2 \mathrm{M} \mathrm{CaCl}$, solution. The beads ( $2 \pm 0.16 \mathrm{~mm}$ diameter) were kept in the $\mathrm{CaCl}_{2}$ solution for 30 min., under gentle stirring, washed with distilled water to eliminate the $\mathrm{CaCl}_{2}$, filtered under vacuum and used as wet gels (G8).

\section{Procedure 3. Entrapment in mixed silica-alginate gels}

The method is also based on the procedure described by Konsoula \& Liakopoulou-Kyriakides (Konsoula \& Liakopoulou-Kyriakides, 2006). Part of the 2\% sodium alginate solution was replaced by sol to obtain a solution with $4 \%$ of aged sol in the final volume $(1.132 \mathrm{~mL}$ of $2 \%$ sodium alginate and $47.2 \mu \mathrm{L}$ of sol from TEOS or $0.904 \mathrm{~mL}$ of $2 \%$ natrium alginate and $37.7 \mu \mathrm{L}$ of sol from TMOS). Then, the enzymes were immobilized and the beads were treated as described in Procedure 2 (G9-G11).

\section{Procedure 4. Entrapment in alginate gels coated with silica}

According to the method used by Won and others (Won et al., 2005), alginate beads (1 g) obtained as described in Procedure 2 were coated with hexane, then 1 $\mathrm{mL}$ aged sol (TEOS/EG or TMOS/EG) or $1 \mathrm{~mL}$ THEOS was added. The beads were kept at $4^{\circ} \mathrm{C}$ overnight, filtered and assayed (G12-G14).

\section{Assay of enzymatic activity and protein content}

The CMCase and cellobiase activities were measured by UV-VIS spectrometry, according to the Petterson and Porath method described by Iordachescu \& Dumitru (Iordachescu \& Dumitru, 1980).

The CMCase activity was measured using $\mathrm{CMC}$ as the substrate and DNS as the reagent. $0.2 \mathrm{~mL}$ of the enzyme solution or $100 \mathrm{mg}$ of immobilized enzyme and $2 \mathrm{~mL}$ of $1 \% \mathrm{CMC}$ in $0.1 \mathrm{M}$ citric acid - $0.2 \mathrm{M} \mathrm{Na}_{2} \mathrm{HPO}_{4}$ buffer, $\mathrm{pH}$ 4.6, were incubated at $50^{\circ} \mathrm{C}$ for 10 minutes. The reaction was stopped by adding $3 \mathrm{~mL}$ of the DNS solution $(0.25 \mathrm{~g}$ DNS in $5 \mathrm{~mL}$ of $2 \mathrm{~N} \mathrm{NaOH}$ and $7.5 \mathrm{~g}$ potassium sodium tartrate dissolved in $25 \mathrm{~mL}$ of distilled water) and by boiling for 15 minutes. The reducing sugars were assayed by measuring absorbance at $640 \mathrm{~nm}$ against a blank, in concordance with a standard curve, with a UVVIS spectrometer (PG Instrument T60U Spectrophotometer, room temperature). One unit of the CMCase activity is defined as the amount of enzyme that hydrolyses CMC liberating $1 \mathrm{mmol}_{\text {glucose }} \times \mathrm{mL}^{-1} \times \mathrm{min}^{-1}$, at $50^{\circ} \mathrm{C}$.

For cellobiase activity measurements, the reaction mixture $(0.2 \mathrm{~mL}$ of the enzymatic solution and $2 \mathrm{~mL}$ of $0.1 \%$ cellobiose solution in $0.1 \mathrm{M}$ citric acid $-0.2 \mathrm{M}$ $\mathrm{Na}_{2} \mathrm{HPO}_{4}$ buffer, $\mathrm{pH} 4.6$ ) was incubated at $50^{\circ} \mathrm{C}$ for 20 minutes. The reaction was stopped by adding $3 \mathrm{~mL}$ of the DNS solution and by boiling for 15 minutes. The 
reducing sugars were assayed at $640 \mathrm{~nm}$ against a blank, using a standard curve. One unit of activity is defined as the amount of enzyme that hydrolyses cellobiose liberating $1 \mathrm{mmol}_{\text {glucose }} \times \mathrm{mL}^{-1} \times \mathrm{min}^{-1}$, at $50^{\circ} \mathrm{C}$.

The FPase activity was measured by using filter paper (FP) as the substrate, by UV-VIS spectrometry, according to the Peitersen method described by Iordachescu \& Dumitru (Iordachescu \& Dumitru, 1980). The hydrolytic activity was tested by using Whatman no. 1 filter paper. The reaction mixture $(50 \mathrm{mg}$ of Whatman no. 1 filter paper strips $1 / 6 \mathrm{~cm}, 1 \mathrm{~mL}$ of 0.1 $\mathrm{M}$ citric acid - $0.2 \mathrm{M} \mathrm{Na}_{2} \mathrm{HPO}_{4}$ buffer, $\mathrm{pH} 4.6$, and 1 $\mathrm{mL}$ of enzymatic solution) was incubated at $50^{\circ} \mathrm{C}$ for one hour. The reducing sugar was determined using 3 $\mathrm{mL}$ of DNS and boiling for 15 minutes. One filter paper unit is the amount of enzyme that produces $1 \mathrm{mg}$ of glucose, at $50^{\circ} \mathrm{C}$, in one hour.

Protein content was assayed according to the Lowry method, using the Folin-Ciocalteu's phenol reagent and bovine serum albumin (BSA) as a standard (Lowry et al., 1951), as follows: $100 \mu \mathrm{L}$ of the enzymatic solution or 50 $\mathrm{mg}$ of the immobilized enzyme, $100 \mu \mathrm{L}$ of distilled water, $5 \mathrm{~mL}$ of reagent $\mathrm{A}+\mathrm{B} 50: 1 \mathrm{w} / \mathrm{w}(\mathrm{A}-4 \mathrm{~g}$ of $\mathrm{NaOH}$, $10 \mathrm{~g}$ of $\mathrm{Na}_{2} \mathrm{CO}_{3}$ and $0.2 \mathrm{~g}$ of potassium natrium tartrate dissolved in $1000 \mathrm{~mL}$ of distilled water, $\mathrm{B}-0.5 \% \mathrm{CuSO}_{4}$ solution) and $0.5 \mathrm{~mL}$ of the Folin-Ciocalteu's reagent (dilution 1:2 in distilled water) were incubated for 30 minutes at room temperature. The protein content was determined by measuring absorbance at $660 \mathrm{~nm}$ against a blank.

In this study, the immobilization experiments were carried out in triplicates. The results shown are expressed as mean values with standard deviation.

\section{CMCase controlled release}

An appropriate amount of gel (1 g) containing the immobilized $T$. viride enzyme was placed in a release medium $\left(5 \mathrm{~mL}\right.$ of $0.1 \mathrm{M}$ citric acid - $0.2 \mathrm{M} \mathrm{Na}_{2} \mathrm{HPO}_{4}$ buffer, pH 2.2 , at $37^{\circ} \mathrm{C}$ ). Samples were withdrawn at predetermined time intervals and then the withdrawn volume was replaced with a fresh buffer solution. The amount of CMCase released from the gels was evaluated using the Petterson and Porath method (Iordachescu \& Dumitru, 1980).

CMCase release $(\%)=100 \times \mathrm{U}_{(\mathrm{im})} / \mathrm{U}_{(\mathrm{i})}$,

where:

$\mathrm{U}_{(\mathrm{i})}=$ activity of the enzyme in the gel used in controlled release studies

$\mathrm{U}_{(\mathrm{im})}=$ activity of the enzyme released from gels $(\mathrm{U} / \mathrm{mL}) \times$ total volume of release media $(\mathrm{mL})$;

$\mathrm{U}_{(\mathrm{i})}=\left(\mathrm{U}_{\mathrm{tot}(\mathrm{i})}-\mathrm{U}_{\mathrm{tot}(\mathrm{w})}\right) / \mathrm{m}_{\mathrm{tot}}$

where:

$\mathrm{U}_{\text {tot(i) }}=$ activity of native enzyme $(\mathrm{U} / \mathrm{mg}) \times$ total weight of native enzyme used for immobilization $(\mathrm{mg})$;

$\mathrm{U}_{\mathrm{tot}(\mathrm{w})}=$ activity of the enzyme in supernatant and washings $(\mathrm{U} / \mathrm{mL}) \times$ total volume of enzyme in supernatant and washings (mL);

$\mathrm{m}_{\mathrm{tot}}=$ total weight of immobilized enzyme obtained after drying.

\section{Characterization of the silica matrix}

The water content of the gels used in activity measurements was determined using a Radwag WPS $210 \mathrm{~S}$ type thermobalance.

For the SEM and Energy Dispersive X-Ray Analysis (EDAX) imaging analysis, the samples were mounted on a conductive aluminum pin stub (specimen mount) using adhesive carbon discs on both sides (Patrick, 2009). The samples were metallized with gold using a sputter coater Agar with a layer of $3 \mathrm{~nm}$ thickness/deposition for 3 times. SEM analysis parameters were HV mode, $20 \mathrm{kV}$, ETD, spot 5, 2 magnification order 100-181x for a general overview image and 12.000x for surface and fracture morphology side of gel beads. For EDAX, the samples were examined without gold sputtering on their surface. EDAX analysis parameters were $\mathrm{HV}$ mode, $15 \mathrm{kV}, \mathrm{ETD}$, EDAXD, spot 5, WD $10 \mathrm{~mm}$.

The thermogravimetric analysis TG/DTG/HF measurements were performed on a Perkin Elmer Diamond device, in air, at a heating rate of $10^{\circ} \mathrm{C} \times \mathrm{min}^{-1}$.

The matrices were dried under vacuum and FT-IR spectra of $\mathrm{KBr}$ pellets were recorded using a Jasco FTIR 430 spectrometer on $400-4000 \times \mathrm{cm}^{-1}$ range at $4 \mathrm{~cm}^{-1}$ spectral resolution.

\section{RESULTS AND DISCUSSION}

\section{Enzyme immobilization using different matrix precursors}

The Trichoderma viride CMGB 1 strain was cultivated in solid state fermentation and the product was extracted and concentrated as described in Materials and methods section 2.2. The obtained aqueous solution had $2.7 \pm 0.2$ $\mathrm{U} / \mathrm{mL}$ CMCase ( $\beta$-1,4-endoglucanase) activity, $1.0 \pm 0.1$ $\mathrm{U} / \mathrm{mL}$ cellobiase activity and $0.11 \pm 0.06 \mathrm{U} / \mathrm{mL}$ FPase $(\beta-1,4$-exoglucanase) activity. The crude powder obtained by lyophilisation had a CMCase activity of $286.7 \pm 23.9$ mmol $\times \mathrm{min}^{-1} \times \mathrm{g}^{-1}$ and a protein content of $226.6 \pm 14.3$ $\mathrm{mg}_{\mathrm{BSA}} \times \mathrm{g}^{-1}$. Considering its high CMCase activity, the product was used in immobilization experiments without purification. The enzyme was entrapped in silica gels, using three precursors, TEOS (G1, G2, G3), TMOS (G4, G5, G6) and THEOS (G7). The enzyme was also entrapped in Ca-alginate gels (G8) and in a combination of these gels (G9-G14) (Table 1).

Considering the CMCase activity of the washings, the amount of enzyme immobilized in the gel can be calculated as the difference between the activity of the enzyme used for immobilization and the enzyme activity of the washings. Usually, the activity loss in the washings is low and the reported immobilization yields are high (Table 1) (Saleem et al., 2005). The same discussion is valid for the protein content. But most of the protein is entrapped in the gel. The availability of active enzyme in the matrix and the enzyme-substrate interaction are influenced by a number of phenomena, such as the diffusion of substrates and products through the porous matrix structure, protein-network interaction or protein aggregation and/or unfolding that usually lead to a loss in catalytic efficiency. If gels are used in the assays, the activity and protein content of the available active enzyme can be determined. Even though the yields were lower, this approach may be useful in further enzyme delivery studies. The unpurified enzyme used in experiments could be another explanation for the lower activities and protein contents, probably due to the additives/ impurities occurring in the crude enzyme product (Vieira et al., 2011).

The best CMCase activity was obtained in Ca alginate, in wet beads (G8), which could explain the higher activities. Significantly lower activities were obtained for immobilization in TEOS and TMOS-derived silica gels (G1 and G4), as compared with alginate. This was probably 
Table 1. Entrapment of CMCase in silica gels, Ca-alginate gel and mixed silica-alginate or silica/alginate gels.

The Trichoderma viride lyophilized $C M C$ ase was immobilized by entrapment in silica gels $\left(G_{1}-G_{7}\right)$, $C^{2}-a l g i n a t e ~ g e l ~\left(G_{8}\right)$ and mixed silicaalginate or silica/alginate gels $\left(G_{9}-G_{14}\right)$. The enzyme was entrapped in the gels $G_{1}-G_{14}$ during the gelification step. The silica gels were synthetized by the sol-gel method (a two-step procedure). The organoalkoxysilane precursors used for synthesis were: TEOS ( $\mathrm{G}_{1}-\mathrm{G}_{3}$ ), $\mathrm{TMOS}$ $\left(G_{4}-G_{6}\right)$, THEOS $\left(G_{7}\right)$. Co-solvents used were: ethanol $\left(G_{1}, G_{4}\right)$ and ethylene glycol $\left(G_{2}, G_{3}, G_{5}, G_{6}, G_{9}, G_{10}, G_{12}, G_{13}\right)$. The silica sols based on ethylene glycol were used fresh $\left(G_{2}, G_{5}\right)$ or aged $\left(G_{3}, G_{6}, G_{9}, G_{10}, G_{12}, G_{13}\right)$. The mixed silica-alginate gels were obtained by replacing part of the sodium alginate solution with sol $\left(\mathrm{G}_{9}-\mathrm{G}_{11}\right)$. The combined silica/alginate gels were obtained by entrapment of enzyme in alginate pearls and coating the pears with aged sol $\left(\mathrm{G}_{12}-\mathrm{G}_{14}\right)$.

\begin{tabular}{|c|c|c|c|c|c|c|}
\hline \multirow{2}{*}{ Gel No. } & \multirow{2}{*}{$\begin{array}{l}\text { Matrix or } \\
\text { gel precursor }\end{array}$} & \multirow{2}{*}{ Water content (\%) } & \multirow{2}{*}{ 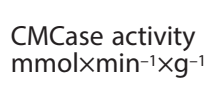 } & \multirow{2}{*}{$\begin{array}{l}\text { Protein content } \\
\mathrm{mgBSA} / \mathrm{g}\end{array}$} & \multicolumn{2}{|c|}{ Immobilization yield (\%) } \\
\hline & & & & & Effective $^{a}$ & Theoretical $^{\mathrm{b}}$ \\
\hline G1 & TEOS/EtOH & $51.9 \pm 4.6$ & $2.7 \pm 0.5$ & $14.8 \pm 1.3$ & $3.5 \pm 0.2$ & $99.6 \pm 1.8$ \\
\hline $\mathrm{G} 2$ & TEOS/EG & $43.3 \pm 3.9$ & $4.4 \pm 0.7$ & $20.7 \pm 1.9$ & $16.0 \pm 1.3$ & $95.2 \pm 3.7$ \\
\hline G3 & TEOS/EG (aged) & $38.8 \pm 2.7$ & $7.4 \pm 0.6$ & $23.0 \pm 2.0$ & $10.3 \pm 1.4$ & $99.8 \pm 1.5$ \\
\hline G4 & TMOS/EtOH & $47.4 \pm 4.6$ & $1.8 \pm 0.1$ & $12.5 \pm 1.1$ & $2.8 \pm 0.1$ & $99.9 \pm 1.7$ \\
\hline G5 & TMOS/ EG & $41.5 \pm 3.9$ & $2.0 \pm 0.4$ & $16.4 \pm 1.4$ & $4.2 \pm 0.4$ & $97.5 \pm 2.6$ \\
\hline G6 & TMOS/EG (aged) & $36.2 \pm 3.8$ & $2.2 \pm 0.2$ & $21.8 \pm 1.9$ & $2.8 \pm 0.4$ & $99.8 \pm 1.4$ \\
\hline G7 & THEOS & $48.7 \pm 4.6$ & $6.4 \pm 0.8$ & $26.2 \pm 2.4$ & $33.2 \pm 4.9$ & $92.9 \pm 4.1$ \\
\hline G8 & Alginate (wet gels) & $92.3 \pm 8.8$ & $12.9 \pm 1.0$ & $8.0 \pm 0.7$ & $25.5 \pm 2.3$ & $68.4 \pm 4.9$ \\
\hline G9 & TEOS/EG/alginate & $91.1 \pm 8.2$ & $6.3 \pm 0.8$ & $9.1 \pm 0.8$ & $11.2 \pm 1.4$ & $68.3 \pm 4.4$ \\
\hline G10 & TMOS/ EG /alginate & $90.8 \pm 7.6$ & $7.5 \pm 0.7$ & $8.9 \pm 0.7$ & $17.1 \pm 1.6$ & $70.1 \pm 4.7$ \\
\hline G11 & THEOS/alginate & $94.1 \pm 8.9$ & $11.3 \pm 0.9$ & $10.4 \pm 0.9$ & $19.8 \pm 1.7$ & $66.7 \pm 4.9$ \\
\hline G12 & Alginate coated with TEOS/EG & $78.4 \pm 7.1$ & $6.5 \pm 0.6$ & $7.3 \pm 0.6$ & $20.1 \pm 1.9$ & $94.8 \pm 4.1$ \\
\hline G13 & Alginate coated with TMOS/EG & $75.9 \pm 6.8$ & $10.9 \pm 0.9$ & $8.9 \pm 0.7$ & $24.0 \pm 2.6$ & $95.2 \pm 3.7$ \\
\hline G14 & Alginate coated with THEOS & $75.4 \pm 6.7$ & $14.7 \pm 1.2$ & $9.6 \pm 0.8$ & $25.4 \pm 2.7$ & $91.2 \pm 4.9$ \\
\hline
\end{tabular}

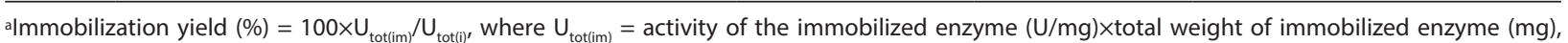
$U_{\text {tot(i) }}=$ activity of the native enzyme $(\mathrm{U} / \mathrm{mg}) \times$ total weight of native enzyme used for immobilization $(\mathrm{mg})$; ${ }^{\text {b }}$ Immobilization yield $(\%)=100 \times U_{\text {tot }}(\mathrm{w}) /$ $U_{\text {tot(i) }}^{\text {tot(i) }}$, where $U_{\text {tot( }(\mathrm{w})}=$ activity of enzyme in supernatant and washings $(\mathrm{U} / \mathrm{mL}) \times$ total volume of supernatant and washings $(\mathrm{mL})$, $U_{\text {tot(i) }}=$ activity of native enzyme (U/mg) xtotal weight of native enzyme used for immobilization (mg);

due to the tight structure of the matrix in the air-dried powder (xerogel). The collapse of the pores and shrinkage of the gel at drying, even under mild conditions, is expected to lower the activity. Despite this, the silica gel matrix has a series of advantages, which reside in its inorganic nature, such as good mechanical stability and resistance to microbial attack (Coradin et al., 2006). The lowest activity was obtained using TMOS, which according to the literature is probably the most widely used silica precursor (Brinker \& Scherer, 1990).

Coating alginate beads with silica gels has proven effective in obtaining immobilized cellulase with higher enzymatic activity. The CMCase of alginate coated with THEOS showed the highest increase compared to the other gels, being closely followed by alginate coated with TMOS/EG. The CMCase activity of alginate coated with TMOS/EG was five times higher than the activity of TMOS/EtOH or TMOS/EG gels (Table 1). By this method, the advantages of the two matrices were combined for more efficient immobilized cellulases with higher activities and higher effective immobilization yields.

\section{Alcohols' influence}

When using THEOS as a gel precursor, two major differences have to be mentioned when comparing with TEOS or TMOS: a) neither organic solvent nor catalyst are needed for the sol synthesis, b) the ethylene glycol produced in the hydrolysis-condensation reactions may influence the microenvironment in the matrix and the enzyme-network interaction with impact on the enzyme's structure and activity.
Usually, the sol is obtained in a ternary system: alcoxisilane/water/alcohol (ethanol or methanol). In our studies, we used ethylene glycol as an effective biocompatible alternative to ethanol in the sol synthesis: TEOS/ $\mathrm{EtOH} /$ water or TMOS/EtOH/water in a molar ratio of $3 / 8.7 / 11$ and TEOS/EG or TMOS/EG in a molar ratio of $3 / 8.95$ (extra water is not needed). Considering that the sols based on TEOS/EG or TMOS/EG can be preserved at low $\mathrm{pH}$ and low temperature for months without gelling, we used both, freshly prepared and aged sols (preserved at $4^{\circ} \mathrm{C}$ for 20 days) in the CMCase immobilization experiments. The results are shown in Table 1 (G2, G3, G5, G6).

For TEOS, the activities are about three times higher using the aged sol and can be compared with those obtained using THEOS. These results proved that TEOS/ ethylene glycol and ethylene glycol/TMOS systems are good alternatives for THEOS.

\section{Mixed gels}

To benefit from the advantages of the two entrapment procedures, in silica and alginate gels, we used a combined method, in two variants: a) synthesis of the gel from a mixture of the two gel precursors (mixture of sol and alginate) and enzyme solution (as shown in Table 1 for G9, G10 and G11), and b) the Ca-alginate gels containing the entrapped enzyme coated with silica gel synthesized using TEOS/EG, TMOS/EG sol or THEOS (as shown in Table 1 for G12, G13, G14).

Using TEOS or TMOS based sols in a mixture with Ca-alginate (variant a), 50\% and 40\% decrease in the yield of reducing sugars was obtained, when compared with alginate (Konsoula \& Liakopoulou-Kyriakides, 
2006). An increase in activity and protein content was achieved in variant $b$, the results being comparable with the entrapment in Ca-alginate wet gels. The THEOS/ alginate combination gave the best results. In the case of alginate gels covered by THEOS or especially TEOSbased silica, robust and biologically stable beads were obtained that did not shrink by drying or swallow in buffer at room temperature as alginates usually did.

The "effective" protein content is also shown for these samples as a measure of accessibility of the substrate or analytes to the enzyme. In the case of alginate gels, even though some protein was lost in the washings (Nochos et al., 2008), the activity is higher. So, the alginate beads covered by THEOS based silica gels could be an alternative to improve the mechanical properties and the resistance to microbial attack of Ca-alginate gels.

\section{Release of CMCase}

Being a non-invasive method, entrapment of enzymes in gels does not significantly alter the most important operational properties. So, the optimum $\mathrm{pH}$ of the free CMCase is 3.0 , the optimum temperature range is $50-70^{\circ} \mathrm{C}$ (where more than $90 \%$ of the enzyme's activity is preserved), the catalytic efficiency $V_{\max } \times 1000 / K_{\mathrm{M}}$ is 155.7 $\mu \mathrm{mol}_{\text {glucose }} \times \mathrm{mg}^{-1} \times \mathrm{min}^{-1}$. By entrapment in $\mathrm{TEOH} /$ EtOH and THEOS based silica gels (G1 and G7), as described in (Dragomirescu et al., 2012), the optimum $\mathrm{pH}$ is shifted by $1-2$ units to higher values, while the optimal temperature is lower, but above the normal temperature in the living organisms $\left(40-60^{\circ} \mathrm{C}\right.$ for THEOS based silica gels). Stability tests show that the products preserve about $62 \%$ and $55 \%$ of activity, respectively, at $\mathrm{pH} 2.6$ and $37^{\circ} \mathrm{C}$, without any preserving agent (Dragomirescu et al., 2012), being more stable than the crude enzyme. The decrease in catalytic efficiency $(35 \%$ loss for TEOS based gels and 28\% loss for THEOS based gels) is compensated by the stabilizing effect of immobilization and by the need for solid products in formulations. These stability results of entrapped microbial cellulases in silica gels or mixed silica/alginate gels are compatible with the animal digestion cycle and make the products useful as additives in feed biotechnology (Dragomirescu et al., 2011).

Release experiments were performed using the gels based on TEOS, THEOS and/or Ca-alginate (G1, G3, G7, G8, G9, G11, G12 and G14), in $0.1 \mathrm{M}$ citric acid $0.2 \mathrm{M} \mathrm{Na}_{2} \mathrm{HPO}_{4}$ buffer, $\mathrm{pH} 2.2$, at $37^{\circ} \mathrm{C}$ (close to physiological conditions). The results are shown in Fig. 1.

Most of CMCase was released at pH 2.2 in the first 30 minutes, then the release continued with low rate. The best enzyme recovery was obtained for G8 (alginate gels) while the worst recovery was obtained for G1 (TEOS/ $\mathrm{EtOH}$ ). As a rule, the THEOS based gels (G11, G14, G7) gave better results than the similar TEOS based gels (G9, G3, G1), even though in all cases the recovery was below $12 \%$. The G12 sample, with the alginate gel coated with TEOS based silica gel had a release behaviour very different from alginate (G8), proving that the coating prevents enzyme leakage and the release was slowed down (Won et al., 2005).

The release from the porous gel varies in the series of gel or gel precursors (Fig. 1):

\section{TEOS/ETOH $<$ TEOS/EG aged $<$ THEOS $<$ alginate}

We did not observe significant differences for the two mixed gel variants (G9 and G12, or G11 and G14). Even though the best results were obtained using calcium alginate, unfortunately its use has significant draw-

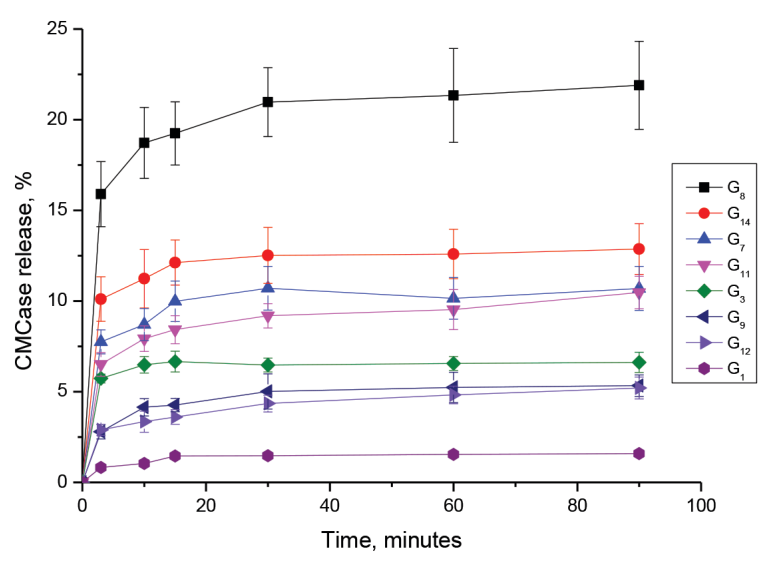

Figure 1. Release curves of CMCase from gels:

G1 - TEOS/ETOH, G3 - TEOS/EG (aged), G7 - THEOS, G8 - alginate, G9 - TEOS/EG/alginate, G11 - THEOS/alginate, G12 - alginate coated with TEOS/EG, and G14 - alginate coated with THEOS. CMCase release $(\%)=100 \times U_{(i \mathrm{~m})} / U_{(\mathrm{i})}$, where $U_{(\mathrm{im})}=$ activity of the enzyme released from gels $(\mathrm{U} / \mathrm{mL}) \times$ total volume of release media $(\mathrm{mL}) ; U_{(i)}=\left(U_{\text {tot(i) }}-U_{\text {tot(w) }}\right) / m_{\text {tot }}$ where $U_{\text {tot(i) }}=$ activity of the native enzyme $(\mathrm{U} / \mathrm{mg}) \times$ total weight of the native enzyme used for immobilization (mg); $U_{\text {tot( }(w)}=$ activity of the enzyme in supernatant and washings $(\mathrm{U} / \mathrm{mL}) \times$ total volume of enzyme in supernatant and washings $(\mathrm{mL}) ; \mathrm{m}_{\text {tot }}=$ total weight of the immobilized enzyme obtained after drying.

backs, such as loss of activity in the dry form, and low mechanical and biochemical stability. Thus, the mixed gels (alginate-THEOS), THEOS or TEOS/EG based gels were the best choice.

It is obvious that the release of enzymes differs from the release of drugs, which are usually small molecules with well-characterized structures. Thus, less enzyme activity recovery was obtained. The results are also influenced in our case by the low $\mathrm{pH}$ of the environment. Some authors suggest that the alginate gel pores drastically collapse at low pH (George \& Abraham, 2006).

\section{Characterization of the silica matrix}

Alginate gels have been well studied for a long time (Sangeetha et al., 2008; Shchipunov et al., 2004; Fundueanu et al., 1999; Vijaya et al., 2008). Nevertheless, a brief look at the main structural features of alginate and/ or silica gels may give a better understanding on the biochemical behaviour of the entrapped enzyme.

The scanning electron microscopy (SEM) images of some relevant samples are presented in Fig. 2. Three different morphological types are observed in the investigated samples (Ludwig, 1998). The first morphological type (G12 - alginate coated with TEOS/EG) is characterized by the presence of an outer and inner layer. The inner layer is homogeneous while the outer layer has a rough surface without surface injury. The second morphological type is represented by samples G3, G6, G7 (silica gels based on TEOS, TMOS and THEOS, respectively). These samples have the silica gel surface covered uniformly in respect to thickness, shape and structure. Nevertheless, some differences can be noticed, i.e. the higher porosity of the gels based on THEOS (G7). The last morphological type is observed in samples G8 and G11 (alginate gels and gels obtained from alginate and THEOS mixture). These beads present a smooth surface with a network of ditches that are joined at different points, forming regular geometric shapes on the surface and increasing the specific surface. 
G12

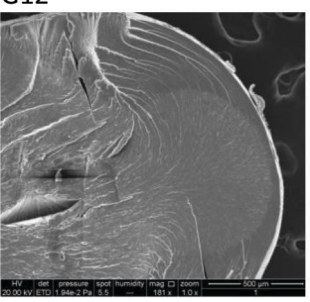

G3

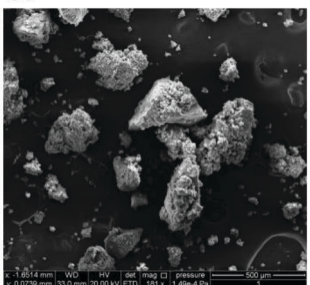

G8

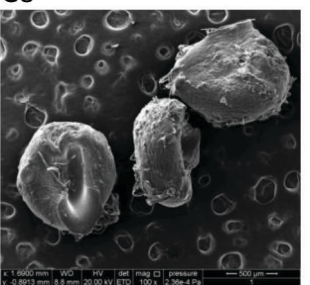

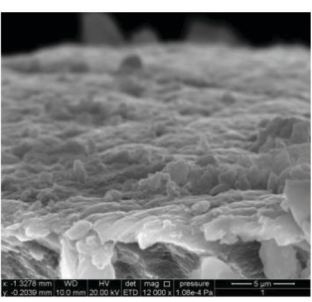
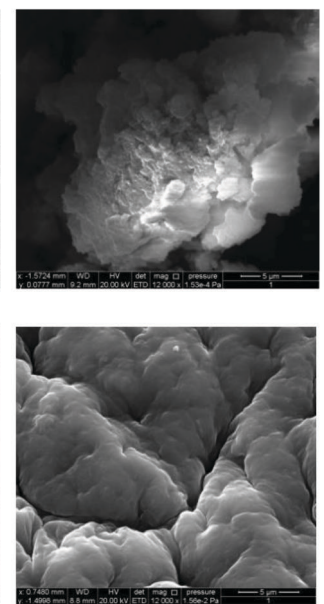

G7

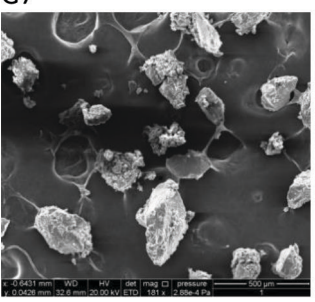

G6

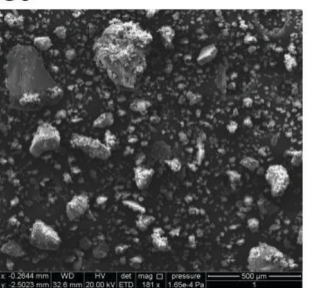

$\mathrm{G} 11$

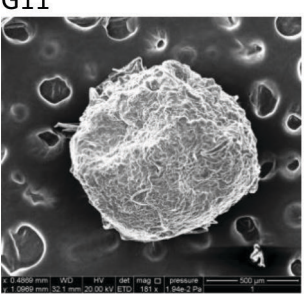

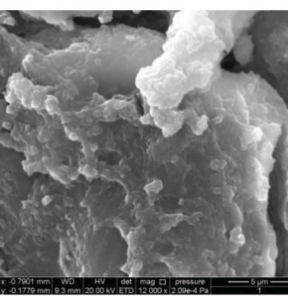
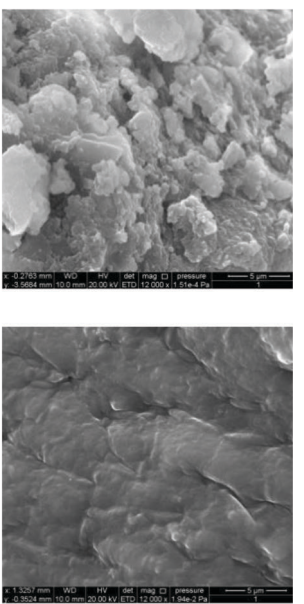

Figure 2. Scanning electron microscopy micrographs and surface morphology of silica and/or alginate gel beads obtained using different precursors

The elemental analysis of the alginate and/or silica gel beads containing immobilized cellulase was performed

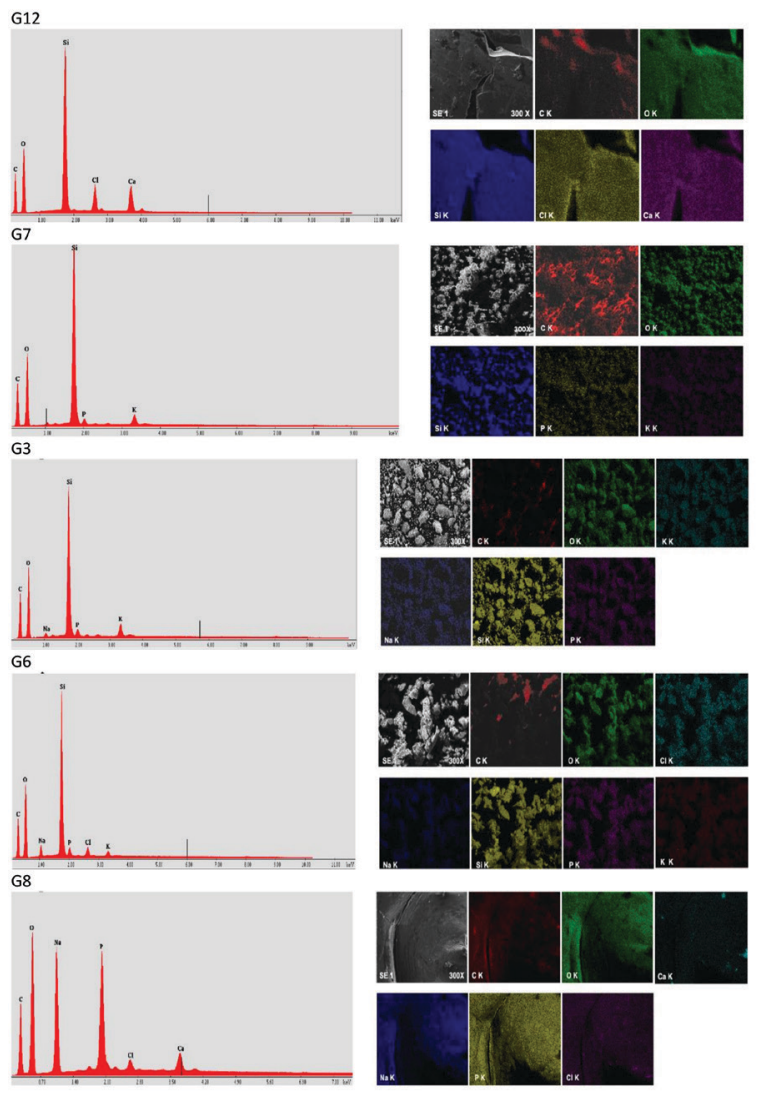

by EDAX spectroscopy (Fig. 3). This analysis showed the presence of carbon in all samples. In sample G12, the chemical elements $\mathrm{O}, \mathrm{Si}, \mathrm{Ca}, \mathrm{Cl}$ were relatively evenly distributed on the surface of the analysed area. In sample G7 and G3, the carbon was in a smaller amount, whereas $\mathrm{O}, \mathrm{Na}, \mathrm{Si}$, and $\mathrm{P}$ were well represented. In sample $\mathrm{G} 6, \mathrm{Si}, \mathrm{O}, \mathrm{Cl}$, and $\mathrm{P}$ were well expressed, while $\mathrm{Na}$ and $K$ were in small amounts. In sample G8 and G11, the elemental analysis evidenced the highest amount of carbon on the surface among all 6 samples analysed. The chemical elements $\mathrm{O}, \mathrm{Si}, \mathrm{Na}$, and $\mathrm{P}$ were well represented, while $\mathrm{Ca}$ and $\mathrm{Cl}$ were in small amounts.

The above remarks are convergent with the thermal analysis of the silica matrices (as shown in Fig. 4). In the case of G1 and G4, a continuous mass loss of about $12 \%$ is observed till $500^{\circ} \mathrm{C}$. For G7, two mass losses for $\mathrm{T}=26-100^{\circ} \mathrm{C}$ and $100-190^{\circ} \mathrm{C}$ endothermic domains are observed, due to the lower molecular mass compounds (ethanol and ethylene glycol), with a mass loss of 10.7 and $12.5 \%$, respectively. The other two domains, an endothermic one $\left(190-290^{\circ} \mathrm{C}\right)$ and an exothermic one (> $290^{\circ} \mathrm{C}$ ) correspond to the products released by the break of Si-C bonds, with a mass loss of $10.6 \%$.

The G2 and G3 thermograms, corresponding to TEOS/EG and TEOS/EG aged sol-gels, have a different and characteristic shape with 2 endo and one exo domain. These three domains for TEOS/EG have maximum temperatures at $142^{\circ} \mathrm{C}, 279^{\circ} \mathrm{C}$ and $371^{\circ} \mathrm{C}$, and

Figure 3. SEM images of the area of interest, and X-ray element mapping.

Microstructural characterization using dispersive $X$-ray spectroscopy (samples G12, G7, G3, G6, G8, G11) (Abbreviations: SE 1 - the $\mathrm{SEM}$ detector used for examination (Secondary Electron detector no. 1); C, Si, O, Na, P, Cl, Ca - chemical elements; $\mathrm{K}$ - energy levels/electron shell - bound to the chemical element's nucleus species; $300 x$ - magnification ratio) 
G7

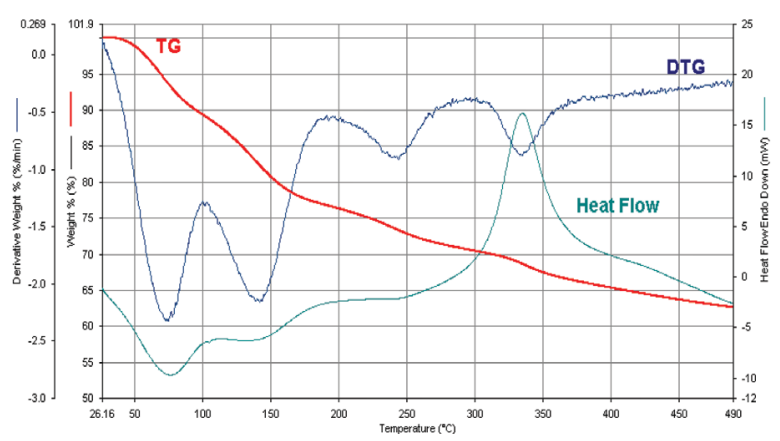

G3

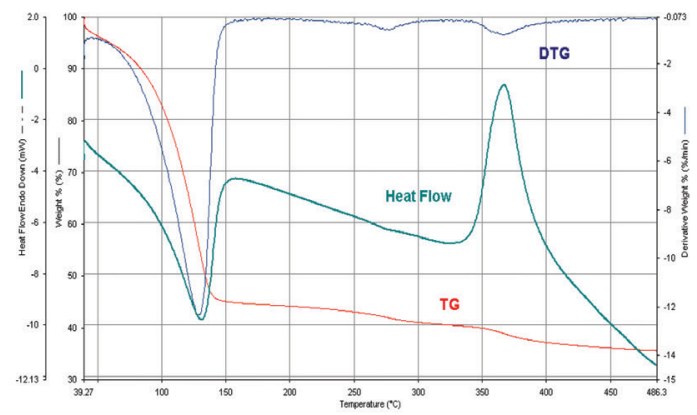

G4

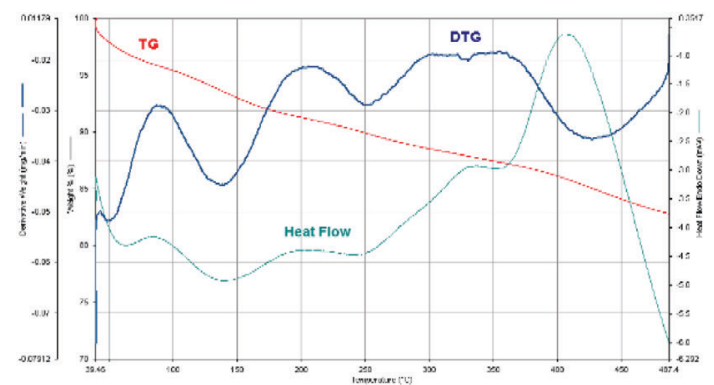

G5

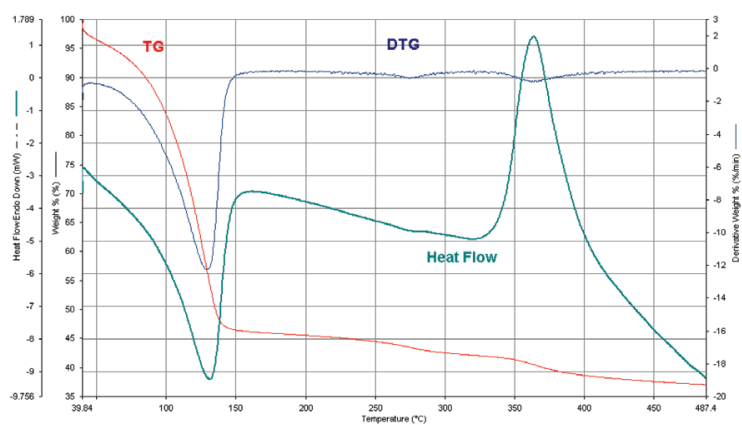

G6

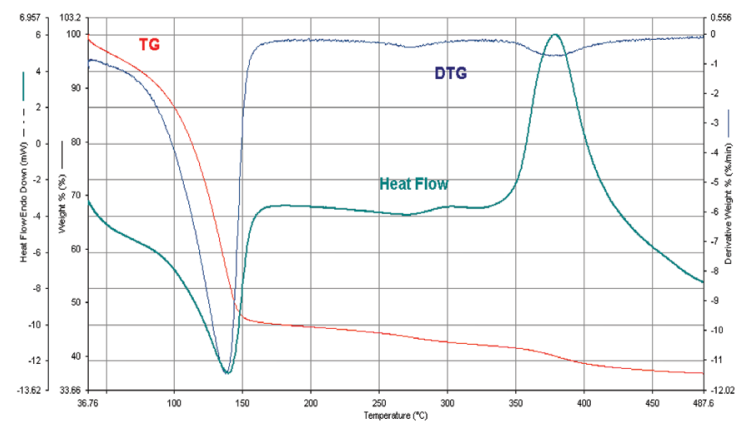

G7

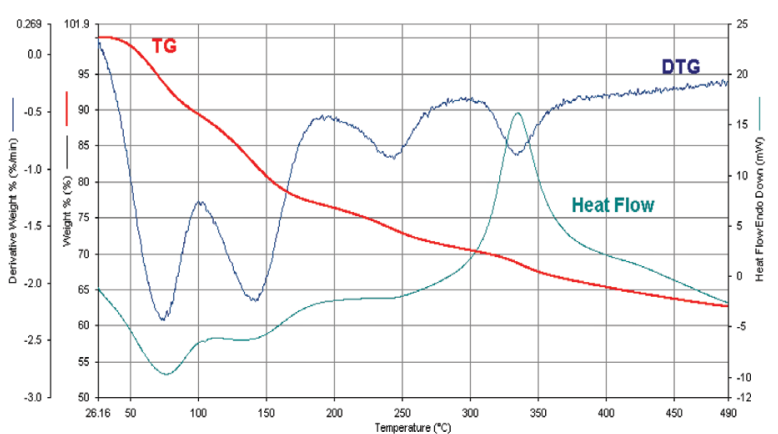

Figure 4. TG/DTG/HF Thermograms of silica gels obtained using different precursors:

G1 - TEOS/EtOH, G2 - TEOS/EG, G3 - TEOS/EG aged, G4 - TMOS/ EtOH, G5 - TMOS/EG, G6 - TMOS/EG aged, and G7 - THEOS.
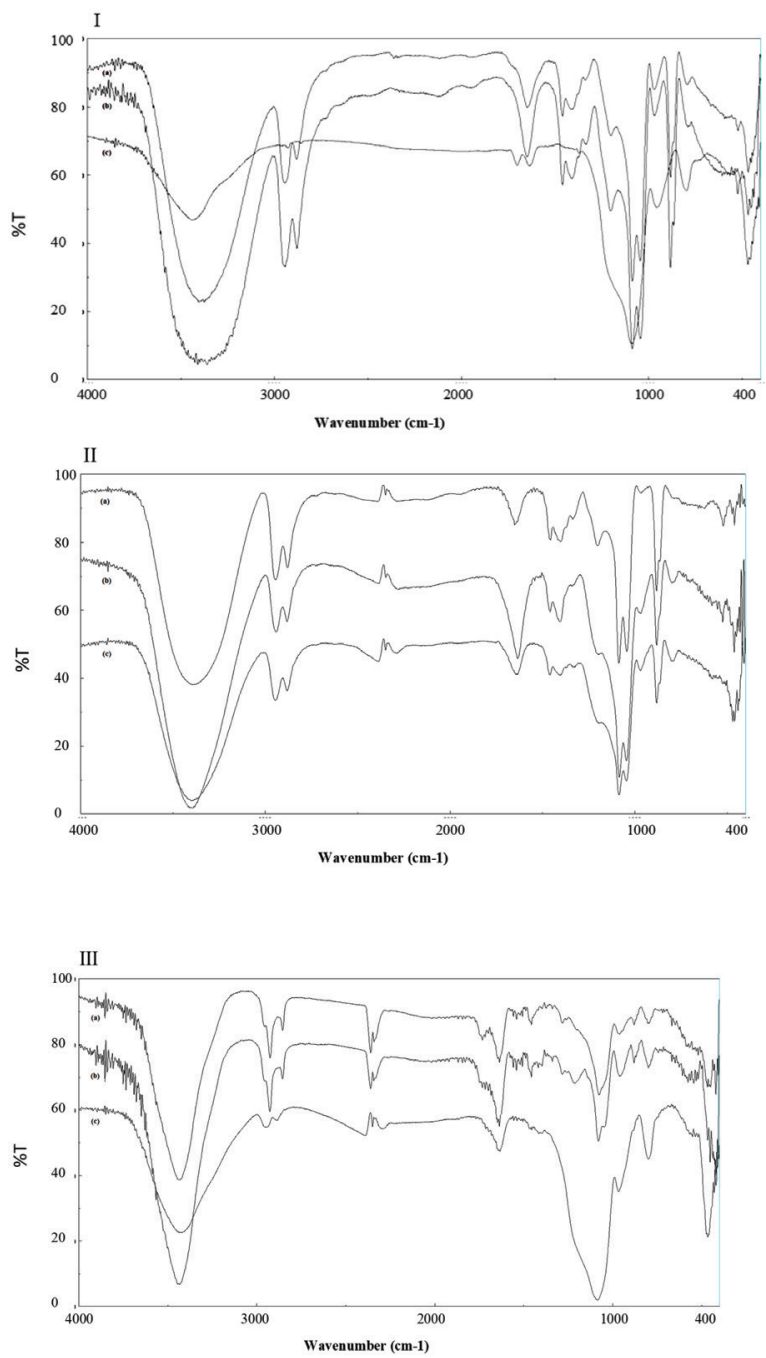

Figure 5. I: FT-IR spectra of TEOS derived silica gels: G1(c), G2 (b), G3 (a); II: FT-IR spectra of THEOS derived silica gels (G7): with 0 (a), 20 (b) and 40 (c) CMCase units/100 mg gel; III: FT-IR spectra of TEOS derived silica gels: G1 (c), G2 (b), G3 (a) (40 CMCase units/100 mg gel) 
weight losses of $60.5 \%, 2.3 \%$ and $3.5 \%$, respectively, corresponding to free, hydrogen-bonded and chemically bonded EG to the silica network, according to Stefanes$\mathrm{cu}$ and others (Stefanescu et al., 2007). For the TEOS/ EG aged sol derived gels, the behaviour is similar, the weight loss being $52.3 \%, 3.2 \%$ and $4.3 \%$, respectively. This data suggest a higher proportion of the stronger bound ethylene glycol.

Among the analytical methods available, the FT-IR spectra analysis could give qualitative structural information on the matrices described in this paper, although FT-IR spectroscopy alone was not able to give information about the exact nature of the binding of ethylene glycol to the silica network. TEOS, TMOS and THEOS sol-gel spectra were recorded as shown in Fig. 5.

As can be seen in Fig. 5.I.a, the spectrum of the TEOS/EtOH gel shows all the characteristic bands of the silica matrix. The most intensive bands, at 1080-1200 $\mathrm{cm}^{-1}$, are attributed to the stretching of Si-O-Si bond. At $3400 \mathrm{~cm}^{-1}$ the vibration of $\mathrm{OH}$, at $1650 \mathrm{~cm}^{-1}$ the deformation of $\mathrm{OH}$ from the incorporated water and residual $\mathrm{Si}-\mathrm{OH}$ bonds are shown. The deformation bands in the 1400-1460 $\mathrm{cm}^{-1}$ region corresponds to the residual ethoxy moiety, if present. The band at $460 \mathrm{~cm}^{-1}$ is probably due to the $\mathrm{Si}-\mathrm{O}$ vibration, at $800 \mathrm{~cm}^{-1}$ to $\mathrm{SiO}_{4}$ tetrahedra, at $595 \mathrm{~cm}^{-1}$ to cyclic Si-O-Si (Rami \& Houssam, 2009; Lenza \& Vasconcelos, 2003).

Figure 5.II a shows the THEOS derived gels' spectra. A deeper and larger band of $\mathrm{OH}$ at $3400 \mathrm{~cm}^{-1}$ indicates more hydrogen-bonded $\mathrm{OH}$ groups, probably due to ethylene glycol and water. Also at 2880 and $2945 \mathrm{~cm}^{-1}$, the characteristic $\mathrm{CH}$ stretching bands in the hydrocarbon chain of organic compounds are shown. A quite intense band at $882 \mathrm{~cm}^{-1}$ corresponds to the deformation of C-C bond from the ethylene group. Also, the band at $1200 \mathrm{~cm}^{-1}$ is attributed to the Si-O-C bending (Stefanescu et al., 2007). The spectra of THEOS sol-gel in Fig. 4.II are quite similar to the TEOS/ethylene glycol spectra in Fig. 5.I.b and 5.I.c, but very different from the spectra of the TEOS/ethanol derived gel (Fig. 5.I.a and 5.III.a).

Figures 5.I and 5.III contain the spectra of TEOS/ EG sol-gels, obtained from fresh or aged sols. A difference between the gels obtained from TEOS/ethanol and TEOS/ethylene glycol is observed. Also, the spectra of the gels obtained from fresh and aged sols are not perfectly identical, suggesting a continuous aging process (low intensity band at $1732 \mathrm{~cm}^{-1}$ ).

The spectra shown in Figs. 5.II.b, 5.II.c and 5.III correspond to immobilized enzymes. Although the protein mass percentage in the matrix is low, the band at 1635 $\mathrm{cm}^{-1}$ can be attributed to the $\mathrm{C}=\mathrm{O}$ from the amidic band of the protein (amide II band). An increase in the enzyme content of the matrix enhances this band when compared with the Si-O-Si stretching bands at 1080$1200 \mathrm{~cm}^{-1}$.

\section{CONCLUSIONS}

Our work suggests that cellulases can be immobilized by entrapment in silica matrices with good immobilization yields. THEOS is a valuable silica precursor for the enzymes' entrapment. A method was developed to mimic THEOS in gel synthesis. The ethylene glycol used as co-solvent for TEOS or TMOS in a sol-gel process acts as both, an active structural component of the matrix and preserving agent for the enzyme. As SEM-EDAX, thermo-gravimetric and FT-IR data suggest, the gels ob- tained using TEOS/EG (aged) or THEOS have some similarities in structure, ethylene glycol being not only entrapped in the matrix, functioning as a spacer, but probably linked by physical and chemical bonds. These precursors can be used in mixed silica/alginate or silicacoated alginate gels, good organic-inorganic hybrid materials for enzyme entrapment.

All the gels tested here for cellulase immobilization have worked as enzyme release systems, proving the most effective ones to be the gels obtained from THEOS, simple or mixed with alginate. Also, the aged gel synthesized from TEOS and EG as co-solvent has been shown here to be effective in releasing cellulases at acidic $\mathrm{pH}$.

\section{Acknowledgments}

The authors would like to acknowledge Prof. Dr. Francisc Péter, Politehnica University of Timisoara, for the FT-IR spectra. Some experiments were performed at the Interdisciplinary Research and Educational Platform "Sustainable ecological agriculture and food safety" from USAMVB Timisoara, Romania.

\section{REFERENCES}

Ajay KP, Sangeeta N (2020) Enhanced cellulase recovery in SSF from Rhizopus oryzae SN5 and immobilization for multi-batch saccharification of carboxymethylcellulose, Biocatal. Agric. Biotechnol. 26: 101656. https://doi.org/10.1016/j.bcab.2020.101656

Avnir D, Braun S, Lev O, Ottolenghi M (1994) Enzymes and other proteins entrapped in sol-gel materials. Chem. Mater. 6: 1605-1614. https://doi.org/10.1021/cm00046a008

Bakunina Y, Nedashkovskaya OI, Zvyagintseva T N, Shchipunov YA (2006) Immobilization of galactosidase inside hybrid silica nanocomposites containing polysaccharides. Russ. J. Appl. Chem. 79: 827-832. https://doi.org/10.1134/S1070427206030260

Bhat MK (2000) Cellulases and related enzymes in biotechnology. Biotechnol. Adv. 18: 355-383. https://doi.org/10.1016/S07349750(00)00041-0

Brinker CJ, Scherer GW (1990) Sol Gel Science. The Physics and Chemistry of Sol-Gel Processing. Academic Press: Boston, USA

Coradin T, Allouche J, Boissière M, Livage J (2006) Sol-Gel Biopolymer/Silica Nanocomposites in Biotechnology. Curr. Nanosci. 2: 1-12. https://doi.org/10.2174/1573413710602030219

Das S, Berke-Schlessel D, Ji HF, McDonough J, Wei Y (2011) Enzymatic hydrolysis of biomass with recyclable use of cellobiase enzyme immobilized in sol-gel routed mesoporous silica. J. Mol. Catal. B: Enzym. 70: 49-54. https://doi.org/10.1016/j.molcatb.2011.02.003

Dinçer A, Telefoncu A (2007) Improving the stability of cellulase by immobilization on modified polyvinyl alcohol coated chitosan beads. J. Mol. Catal. B: En₹ym. 45: 10-14. https://doi.org/10.1016/j. molcatb.2006.10.005

Dragomirescu M, Vintila T, Preda G (2011) Immobilized microbial cellulases in organic-inorganic hybrid materials. Sci. Papers: Anim. Sci. Biotechnol. 44: 380-382

Dragomirescu M, Vintila T, Preda G (2012) Entrapment of microbial amylases and cellulases in silica-gels. Rev. Roum. Chim. 57: 163-168

Fundueanu G, Nastruzzi C, Carpov A, Desbrieres J, Rinaudo M (1999) Physico-chemical characterization of Ca-alginate microparticles produced with different methods. Biomaterials 20: 1427-1435. https:// doi.org/10.1016/s0142-9612(99)00050-2

George M, Abraham TE (2006) Polyionic hydrocolloids for the intestinal delivery of protein drugs: Alginate and chitosan - a review. J. Control. Release 114: 1-14. https://doi.org/10.1016/j.jconrel.2006.04.017

Gill I, Ballesteros A (2000) Bioencapsulation within synthetic polymers (Part 1): sol-gel encapsulated biological. Trends Biotechnol. 18: 282296. https://doi.org/10.1016/s0167-7799(00)01457-8

Haodao M, Jianhui Q, Chao Y, Limin Z, Eiichi S, Jiao C (2020) Porous biochar/chitosan composites for high performance cellulase immobilization by glutaraldehyde, Ensyme Microb. Tech. 138: 109561. https://doi.org/10.1016/j.enzmictec.2020.109561

Husing N, Brandhuber D, Kaiser P (2006) Glycol-modified organosilanes in the synthesis of inorganic-organic silesquioxane and silica monoliths. J. Sol-Gel Sci. Techn. 40: 131-139. https://doi. org/10.1007/s10971-006-8802-z

Iordachescu D, Dumitru IF (1980) Biochimie practica. Tipografia Universitatii Bucuresti: Bucuresti, Romania 
Jin W, Breman JD (2002) Properties and applications of proteins encapsulated within sol - gel derived materials. Anal. Chim. Acta 461: 1-36. https://doi.org/10.1016/S0003-2670(02)00229-5

Kim J, Grate JW, Wang P (2006) Nanostructures for Enzyme Stabilization. Chem. Eng. Sci. 61: 1017-1026. https://doi.org/10.1016/j. ces.2005.05.067

Kim YD, Park CB, Clark DS (2001) Stable sol-gel microstructured and microfluidic networks for protein patterning. Biotechnol. Bioeng. 73. 331-337. https://doi.org/10.1002/bit.1066

Konsoula Z, Liakopoulou-Kyriakides M (2006) Starch hydrolysis by the action of an entrapped in alginate capsules a-amylase from $\mathrm{Ba}$ cillus subtilis. Process Biochem. 41: 343-349. https://doi.org/10.1016/j. procbio.2005.01.028

Lange JP (2007) Lignocellulose conversion: an introduction to chemistry, process and economics. Biofuels Bioproducts Biorefining 1: 39-48. https://doi.org/10.1002/bbb.7

Lenza RFS, Vasconcelos WL (2003) Study of the influence of some DCCAs on the structure of the sol-gel silica membranes. J. NonCryst. Solids 330: 216-225. https://doi.org/10.1016/j.jnoncrysol.2003.07.001

Livage J, Coradin T, Roux C (2001) Encapsulation of biomolecules in silica gels. J. Phys.: Condens. Mat. 13: 673-691. https://doi. org/10.1088/0953-8984/13/33/202

Lowry OH, Rozbrough NJ, Pan LA, Randall RJ (1951) Protein measurement with the Folin phenol reagent. J. Biol. Chem. 193: 265-275

Ludwig R (1998) Scanning Electron Microscopy: Physics of Image Formation Microanalysis, 2nd edn, Springer-Verlag: Berlin Heidelberg, New York

Mitchell DA (1992) Substrates for processes. In Solid Substrate Cultivation. Doelle HW, Mitchell DA, Rolz CA eds, pp 43-46. International Organization of Biotechnology \& Bioengineering, Project 87-02

Nochos A, Douroumis D, Bouropoulos N (2008) In vitro release of bovine serum albumin from alginate/HPMC hydrogel beads. Carbohyd. Polym. 74: 451-457. https://doi.org/10.1016/j.carbpol.2008.03.020

Paljevac M, Primožič M, Habulin M, Novak Z, Knez Ž (2007) Hydrolysis of carboxymethyl cellulose catalyzed by cellulase immobilized on silica gels at low and high pressures. J. Supercrit. Fluid 43: 74-80. https://doi.org/10.1016/j.supflu.2007.05.006

Park CB, Clark DS (2002) Sol-gel encapsulated enzyme arrays for highthroughput screening of biocatalytic activity. Biotechnol. Bioeng. 78: 229-235. https://doi.org/10.1002/bit.10238

Patrick E (2009) Handbook of Sample Preparation for Scanning Electron Microscopy and X-Ray Microanalysis. Springer Science \& Business Media: New York, USA

Rami AO, Houssam ER (2009) Synthesis and characterization of FTIR spectroscopy of silic aerogels prepared using several $\mathrm{Si}(\mathrm{OR})_{4}$ and R"Si(OR) 3 precursors. J. Mol. Struct. 919: 140-145. https://doi. org/10.1016/j.molstruc. 2008.08 .025

Reetz MT, Tielmann P, Wiesenhöfer W, Könen W, Zonta A (2003) Second generation sol-gel encapsulated lipases: robust heterogeneus biocatalysts. Adv. Synt. Catal. 345: 717-728. https://doi. org/10.1002/adsc.200303016

Reetz MT, Wenkel R, Avnir D (2000) Entrapment of lipases in hydrophobic sol-gel materials: Efficient heterogenous biocatalysts in aqueous medium. Synthesis 6: 781-783. https://doi, org/10.1055/s-2000-6276

Reetz MT, Zonta A, Simpelkamp J (1996) Efficient immobilization of lipases by entrapment in hydrofobic sol-gel materials. Biotechnol. Bioeng. 49: 527-534. https://doi.org/10.1002/(SICI)10970290(19960305) 49:5<527::AID-BIT5>3.0.CO;2-L

Saleem M, Rashid MH, Jabbar A, Perveen R, Khalid AM, Rajoka MI (2005) Kinetic and thermodynamic properties of an immobilized endoglucanase from Arachniotuscitrinus. Process Biochem. 40: 849-855

Sangeetha K, Morris VB, Abraham TE (2008) Stability and catalytic properties of encapsulated subtilisin in xerogels of alkoxisilanes.
Appl. Catal. A: Gen. 341: 168-173. https://doi.org/10.1016/j.apcata.2008.02.043

Shchipunov YA, Karpenko TY, Bakunina IY, Burtseva YV, Zvyagintseva TN (2004) A new precursor for the immobilization of enzymes inside sol-gel derived hybrid silica nanocomposites containing polysaccharides. J. Biochem. Bioph. Meth. 58: 25-38. https://doi. org/10.1016/S0165-022X(03)00108-8

Shchipunov YA, Karpenko TY, Krekoten AV (2005) Hybrid organicinorganic nanocomposites fabricated with a novel biocompatible precursor using sol-gel processing. Compos Interfaces 11: 587-607. https://doi.org/10.1163/1568554053148816

Singhania RR, Sukumaran RK, Patel AK, Larroche C, Pandey A (2010) Advancement and comparative profiles in the production technologies using solid-state and submerged fermentation for microbial cellulases. Enayme Microb. Tech. 46: 541-549. http://ir.niist.res.in:8080/ jspui/handle/123456789/1635

Stefanescu M, Stoia M, Stefanescu O (2007) Thermal and FT-IR study of the hybrid ethylene-glycol-silica matrix. J. Sol-Gel Sci. Techn. 41: 71-78. https://doi.org/10.1007/s10971-006-0118-5

Takimoto A, Shiomi T, Ino K, Tsunoda T, Kawai A, Mizukami F, Sakaguchi K (2008) Encapsulation of cellulase with mesoporous silica (SBA-15). Micropor.Mesopor. Mat. 116: 601-606. https://doi. org/10.1016/j.micromeso.2008.05.046

Vieira MF, Marquetotti Salcedo Vieira A, Zanin GM, Tardioli PW, Mateo C, Guisán JM (2011) B-Glucosidase immobilized and stabilized on agarose matrix functionalized with distinct reactive groups. J. Mol. Catal. B: Ensym. 69: 47-53. https://doi.org/10.1016/j.molcatb.2010.12.009

Vijaya Y, Popuri SR, Boddu VM, Krishnaiah A (2008) Modified chitosan and calcium alginate biopolymer sorbents for removal of nickel (II) through adsorption. Carbohyd. Polym. 72: 261-271. https://doi.org/10.1016/j.carbpol.2007.08.010

Wei H, Shuai P, You L, Lulu Y, Ruijiang L (2020) Immobilization and characterization of cellulase on hydroxy and aldehyde functionalized magnetic $\mathrm{Fe}_{2} \mathrm{O}_{3} / \mathrm{Fe}_{3} \mathrm{O}_{4}$ nanocomposites prepared via a novel rapid combustion process. Int. J. Biol. Macromol. 162: 845-852. https://doi. org/10.1016/j.ijbiomac.2020.06.209

Won K, Kim S, Kim KJ, Woo Park H, Moon SJ (2005) Optimization of lipase entrapment in Ca-alginate gel beads. Process Biochem. 40: 2149-2154. https://doi.org/10.1016/j.procbio.2004.08.014

Wongwilaiwalin S, Rattanachomsri U, Laothanachareon T, Eurwilaichitr L, Igarashi Y, Champreda V (2010) Analysis of a thermophilic lignocellulose degrading microbial consortium and multi-species lignocellulolytic enzyme system. Ensyme Microb. Tech. 47: 283-290. https://doi.org/10.1016/j.enzmictec.2010.07.013

Yang W, Chenyu F, Rongxin G, Yifang M, Yu Y, Yanping L (2021) Cellulase immobilized by sodium alginate-polyethylene glycol-chitosan for hydrolysis enhancement of microcrystalline cellulose, Process Biochem. In Press. https://doi.org/10.1016/j.procbio.2021.02.018

Yonca AD, Gamze T, Uğur K (2020) Immobilisation of cellulase on vermiculite and the effects on enzymatic kinetics and thermodynamics. Appl. Clay Sci. 197: 105792. https://doi.org/10.1016/j. clav. 2020.105792

Zarcula C, Croitoru R, Corici L, Csunderlik C, Peter F (2009) Improvement of lipase catalytic properties by immobilization in hybrid matrices. World Acad. Sci., Eng. Technol. 52: 179-184. https://doi. org/doi.org/10.5281/zenodo.1329062

Zheng Z, Xin J, Min Z, Xinqi X, Jiaolong F, Liangzhi L (2019) An enhanced ionic liquid-tolerant immobilized cellulase system via hydrogel microsphere for improving in situ saccharification of biomass, Biores. Technol. 294: 122146. https://doi.org/10.1016/j.biortech.2019.122146 